International Journal of Agriculture, Environment and Bioresearch

Vol. 5, No. 06; 2020

ISSN: $2456-8643$

\title{
HEAVY METALS DEACTIVATION IN SOILS WITH THE HELP OF VARIOUS HUMUS
}

\author{
Boynazarov Bahron Raimovich and Khushvaktov Tuychi Suvanovich \\ Tashkent State Agrarian University, 100140, Universitet Street, 2, Tashkent region, Uzbekistan \\ https://doi.org/10.35410/IJAEB.2020.5594
}

\begin{abstract}
The article provides information on the quality and quantity indicators of soils in the regions of JSC "Almalik mining and Metallurgical Combine" and the fact that $\mathrm{Cu}, \mathrm{Mn}, \mathrm{Zn}, \mathrm{As}, \mathrm{Pb}$ elements increased in soils compared with control, $\mathrm{Ca}$ and $\mathrm{Mg}$ elements decreased in comparison with control. $\mathrm{Cu}, \mathrm{Mn}, \mathrm{Zn}, \mathrm{As}, \mathrm{Pb}$ elements have a toxic property and a decrease in the amount of $\mathrm{Ca}$ and $\mathrm{Mg}$ calcium in the soil in order to reduce the amount of toxic substances in the form in which plants absorb, taking into account the fact that plants adversely affect biophysical and biochemical processes occurring in the corresponding cells and tissues, concrete and humate potassium.
\end{abstract}

Keywords: Humus, Organic Matter, Heavy Metals, Bentonite, Toxic Substances, Soil, Microelements.

\section{INTRODUCTION}

The amount of heavy metals falling into the environment is increasing all over the world due to intensification of production, mining, burning of fuel, fertilizers for agriculture, production and use of pesticides, improper processing of waste, etc. As we know, heavy metals are very toxic to all living organisms. Pollution of the environment with chemicals not only causes the absorption of the biosphere, but also decreases the quality of food products grown .The toxic effect of metals is determined by many factors and, on the one hand, depends on the nature of the element and its concentration, on the other hand, on the physico-chemical properties of the soil, on the activity of soil microorganisms, on the type of plant and the form of deposition of heavy metals in the soil, as well, on the existence of elements [1].

Interest in microelements, including heavy metals, is high when it comes to soil exploration and fertility research. With an increase in the concentration in the cell, the toxicity properties also increase, since elements such as cobalt, copper, iron, manganese, molybdenum, nickel and zinc are important for the life activity of living organisms in small concentrations. For this reason, these elements are often referred to as heavy metals in high concentrations, in most cases, when they are referred to as microelements in small concentrations. Metals such as cadmium, lead and Mercury also have harmful effects at low concentrations [2].

The main negative consequence of damage with toxic substances is the deterioration of the genetic quality of agricultural products. Consumptions of plant products grown in conditions 


\section{International Journal of Agriculture, Environment and Bioresearch}

Vol. 5, No. 06; 2020

ISSN: $2456-8643$

where the environment is contaminated with toxic substances leads to a change in hereditary, immune and metabolic characteristics [3, 4].

In world practice, the following methods have been developed to reduce toxic substances in the soil composition and neutralize them:

- Improvement of air purification equipment of the enterprise;

- Deactivation (treatment of soil with lime and gypsum-retaining agents, coagulants);

- Membrane technology (effective methods of groundwater purification);

- Phytoremediation (neutralization of the pollutants with the help of natural absorbents soil microorganism and higher plants).

Within these methods, the methods of deactivation and phytoremediation play an important role.

The problem of choosing a method of deactivation of heavy metals is primarily due to the variability of the soil cover, significant variability of the agrochemical and ecological-biological properties of its fertility, and, secondly, the degree of technological influence on the soil, which led to the need to analyze the existing activity by linking it to a certain degree of pollution.

The following study [4] uses chemical deactivation methods in hazardous levels of soil pollution with heavy metals, which is based on the interaction of pollutants with soil components due to hydrolysis reactions, oxidation - reduction, chemical sorption, etc. Organic substances, chelates, ion exchange resins, coal, humus, lime, gypsum, chalk, carbonates and potassium sulfide, mineral and organic fertilizers, in other words, mixtures, the main purpose of reducing their translocation in the plant is to form toxic substances that plants cannot absorb the substances or agro-ores become complex that plants cannot assimilate due to the formation of complex compounds with toxic substances, thus having a positive effect on the physical properties of the soil.

Soil minerals and humus substances have the most important properties that control the mobility and biological properties of compounds of elements in land ecosystems [5, 6].

Humic substances contained in the soil solution, in chemical reactions, including in combination with metal ions, can change the properties of the ozone effect with the elements of mineral nutrients, causing complex dressing. They reduce the assimilation by plants of heavy metals due to the fact that metal-humate and metal-humate-mineral, as well as the dressing of chemical bonds with heavy metals due to the relative resistance of soil $\mathrm{pH}$ from soil-ecological conditions, for example, soil solution [7].

From the above information, we can see that humus substances have the property of transferring heavy metals into a non-absorbable form by plants in the form of chemical bonding with heavy metals in the form of organic matter in the soil, that is, in the soil environment and in the form of absorbable by plants. 


\section{International Journal of Agriculture, Environment and Bioresearch}

Vol. 5, No. 06; 2020

ISSN: $2456-8643$

It should be noted that the effect of humic substances on the physiological activity of plants is diverse. In the following studies [8,9], it is shown that when these substances are in the percentage of a fault of ten thousand in the soil solution, both enter the plant body.

Under the influence of humus substances, the root formation in plants is activated; the flow of water and nutritional elements increases due to changes in the selectivity of cell membranes, humus compositions positively affects all phases of the processes that go in the cells. They have the property of participating in physiological and biochemical processes, in oxidation-reduction reactions, activate enzymes, increase respiratory intensiveness, photosynthesis productivity, absorption of mineral elements, and ensure the use of ingested phosphorus in the synthesis of protein substances. When external conditions deviate from the norm, the influence of humus compounds, in particular when the conditions of mineral nutrition of plants, changes in air and soil temperature, changes in the amount of moisture and oxygen in the air and root area, is active. When the course of bioenergetic processes under extreme conditions is disrupted and cannot be restored without additional energy expenditure, their adaptive ability is manifested, which controls the synthesis, repair and regeneration processes of nucleic acids, enzyme proteins and structural proteins. They also absorb nutrients and moisture, thereby protecting nutrients from the transition to underground layers, that is, deeper layers of the plant root zone and groundwater. All this allows to significantly reduce the consumption of mineral fertilizers applied to the soil, increase soil fertility, and improve the quality of products and soil fertility.

Summarizing from the above information, it can be concluded that the application of humic substances and agronomic bentonites in heavy metals to damaged supports not only reduces the harmful effects of heavy metals, but also positively affects the development of plants.

\section{MATERIALS AND METHODS}

This study investigated the effects of humic substances and bentonites on soils damaged by heavy metals. Initially, the JSC "Almalyk mining and Metallurgical combine" (Joint Stock Company), located in the territory of Tashkent region, analyzed the quantities of heavy elements in the soil system, which spread to the environment, and the design of heavy metals in the soil with the help of humic substances and bentonites was carried out.

The research was carried out in the agricultural regions of the Almalik city of Tashkent region and the surrounding regions of JSC "Almalik mining and Metallurgical combine", as well as in the agricultural regions of the combine. Selection of soil samples (soil samples) was carried out at the end of the vegetation period according to GOST (State standards) 17.4.4.02-84.

In order to transfer the heavy elements in the soil to the form of sorption and complex compound formation, the mixture of humate and bentonite was prepared and stored for 7 days after moistening in 10 soil samples taken from 100 gramm and then the total and absorbable amounts of the elements were determined by rotting in $40^{\circ} \mathrm{C}$ mortar. The chemical composition of the used humate potassium and bentonite is given in 1, 2 tables. 
Humate oxidized potassium Angren coal using hydrogen peroxide and then separated the oxidized product by extraction method using 1\% Mining Solution. Its concentration was 3,83\%, the resulting solution was diluted to $0,1 \%$ and added to the soil by various standards. The amount of heavy metals in the soil (ICP-MS) was quantified using 7500 Series device using "atomic emission method with inductively bound plasma and mass spectral method with inductively bound plasma using methods of determination of element composition of Mountain Ash, Earth, soil and underground sediments".

Table 1: The humate potassium content

\begin{tabular}{|l|l|l|l|l|l|}
\hline \multicolumn{1}{|c|}{ № } & Moisture, \% & Ash, \% & $\begin{array}{c}\text { General organic } \\
\text { sustances, \% }\end{array}$ & $\begin{array}{c}\text { Including } \\
\text { humic acids, } \\
\text { \% }\end{array}$ & $\begin{array}{c}\text { Fulvo } \\
\text { acids, \% }\end{array}$ \\
\hline $\begin{array}{l}\text { Humate } \\
\text { potassium }\end{array}$ & 97,17 & 0,11 & 2,72 & 1,42 & 0,24 \\
\hline
\end{tabular}

Table 2: Chemical composition of bentonite, \% (Tashkent region)

\begin{tabular}{|c|c|c|c|c|c|c|c|c|c|c|c|c|}
\hline $\mathrm{SiO}_{2}$ & $\mathrm{~T}_{1} \mathrm{O}_{2}$ & $\mathrm{Al}_{2} \mathrm{O}_{3}$ & $\mathrm{Fe}_{2} \mathrm{O}_{3}$ & $\mathrm{MgO}$ & $\mathrm{MnO}$ & $\mathrm{CaO}$ & $\mathrm{Na}_{2} \mathrm{O}$ & $\mathrm{K}_{2} \mathrm{O}$ & $\mathrm{P}_{2} \mathrm{O}_{5}$ & $\mathrm{SO}_{3}$ & $\mathrm{H}_{2} \mathrm{O}$ & $\mathrm{CO}_{2}$ \\
\hline 50,34 & 0,73 & 15,21 & 5,67 & 2,3 & 0,03 & 4,76 & 2,31 & 2,36 & 0,13 & 1,48 & 5,42 & 3,41 \\
\hline
\end{tabular}

\section{RESULTS AND DISCUSSION}

The main recorded method of taking ES from the distances of 1, 5 and $10 \mathrm{~km}$ from the copper production plants of JSC "Almalyk mining and Metallurgical combine" determined the amounts of elements. As can be seen from Table 1, we can observe that in the soil of $1 \mathrm{~km}$ away from the copper production enterprise, the $\mathrm{Cu}$ element increased by $780 \%$, the $\mathrm{MN}$ element by $109 \%$, the $\mathrm{Zn}$ element by $320 \%$, the As $176 \%$ and the $\mathrm{Pb}$ by $294 \%$ (if the control is taken as 100 percent), the $\mathrm{Ca}$ element decreased by $53 \%$, the Mg. As can be seen from Table 2, we can observe that in the soil $1 \mathrm{~km}$ away from the zinc production plant, the $\mathrm{Cu}$ element increased by $854 \%$, the $\mathrm{Zn}$ element by $2300 \%$ compared to the control (if the control is taken as 100 percent), the $\mathrm{Ca}$ element decreased by $90 \%$, the $M g$ element by $93 \%$ compared to the control. From such results, we can conclude that the concentration of $\mathrm{Cu}$ and $\mathrm{Zn}$ elements in soils in the regions around the copper zinc production plant exceeds the permissible values several times, this leads to the manifestation of toxic properties of these elements, while the decrease in the amount of calcium in the living organism leads to a biophysical and biochemical violation of the cells and tissues.

As noted above, the introduction of various deactivates into the soil leads to a change in the state of heavy elements, when the content of heavy elements in the soil is high in the amount of PN (the permissible norm). It should be noted that they differ from the rest of the studied heavy elements, the formation of the most fortified complex with humic substances for copper is 
Vol. 5, No. 06;2020

ISSN: 2456-8643

characteristic. The stability of copper humus complex is 2-3 times higher than cadmium. The addition of bentonite to the soil leads to a decrease in the mobility of heavy elements.

Table 3: Quantities of elements in soil samples of the territory around the copper plant, g/t

\begin{tabular}{|c|c|c|c|c|c|}
\hline \multirow{2}{*}{$N$} & \multirow{2}{*}{$\begin{array}{c}\text { Element } \\
\mathbf{S}\end{array}$} & $\begin{array}{c}\text { Control, Kukorol } \\
\text { area of Buka } \\
\text { region }\end{array}$ & & $\mathbf{3}$ & \multicolumn{3}{|c|}{ Copper plant regions } \\
\cline { 4 - 6 } & & $41,0 \pm 0,12$ & $320 \pm 0,16$ & $300 \pm 0,16$ & $230 \pm 0,24$ \\
\hline 1 & $F e$ & $64000 \pm 1,6$ & $34000 \pm 1,2$ & $36000 \pm 1,4$ & $39000 \pm 1,3$ \\
\hline 2 & $M g$ & $850 \pm 0,2$ & $930 \pm 0,24$ & $910 \pm 0,16$ & $740 \pm 0,18$ \\
\hline 3 & $Z n$ & $30000 \pm 10,4$ & $38000 \pm 13,2$ & $27000 \pm 14,4$ & $24000 \pm 8,4$ \\
\hline 4 & $A s$ & $16000 \pm 8,8$ & $15000 \pm 10,4$ & $13000 \pm 10$ & $9100 \pm 8,4$ \\
\hline 5 & $P b$ & $100 \pm 0,24$ & $320 \pm 0,32$ & $320 \pm 0,36$ & $400 \pm 0,36$ \\
\hline 6 & $M n$ & $29,0 \pm 0,28$ & $51,0 \pm 0,36$ & $36,0 \pm 0,28$ & $37,0 \pm 0,16$ \\
\hline 7 & $F e$ & $51,0 \pm 0,36$ & $150,0 \pm 0,28$ & $130,0 \pm 0,16$ & $200 \pm 0,32$ \\
\hline 8 & $M g$ & & & & \\
\hline
\end{tabular}

Note: Soil samples with a depth of $0-10 \mathrm{~cm}$

Table 4: Quantities of elements in soil samples of the territory around the zinc plant, g/t

\begin{tabular}{|c|c|c|c|c|}
\hline \multirow{2}{*}{ № } & \multirow{2}{*}{ Elements } & \multirow{2}{*}{$\begin{array}{c}\text { Control, Kukorol } \\
\text { area of Buka region }\end{array}$} & \multicolumn{2}{|c|}{$1 \mathrm{~km}$ away from plant } \\
\hline & & & $0-10 \mathrm{~cm}$ depth & $10-20 \mathrm{~cm}$ depth \\
\hline 1 & $Z n$ & $100 \pm 0,12$ & $2300 \pm 5,6$ & $2300 \pm 4,4$ \\
\hline 2 & $\mathrm{Cu}$ & $41 \pm 0,28$ & $350 \pm 0,4$ & $360 \pm 0,44$ \\
\hline 3 & $\mathrm{Na}$ & $12000 \pm 10$ & $9900 \pm 7,6$ & $10000 \pm 9,2$ \\
\hline 4 & $P$ & $940 \pm 0,4$ & $970 \pm 0,36$ & $1000 \pm 2$ \\
\hline 5 & $K$ & $17000 \pm 8,8$ & $19000 \pm 9,2$ & $18000 \pm 11,6$ \\
\hline 6 & $\mathrm{Ca}$ & $64000 \pm 12$ & $58000 \pm 8,5$ & $54000 \pm 8,6$ \\
\hline 7 & $M n$ & $850,0 \pm 0,52$ & $870,0 \pm 0,44$ & $890,0 \pm 0,48$ \\
\hline 8 & $\mathrm{Fe}$ & $30000,0 \pm 11,6$ & $33000,0 \pm 12,6$ & $35000,0 \pm 12,1$ \\
\hline
\end{tabular}


International Journal of Agriculture, Environment and Bioresearch

Vol. 5, No. 06; 2020

ISSN: 2456-8643

\begin{tabular}{|l|l|l|l|l|}
\hline 9 & $M g$ & $16000 \pm 10,2$ & $13000 \pm 9,8$ & $12000 \pm 8,7$ \\
\hline
\end{tabular}

Preliminary research conducted on 100 gr of soil sample $1 \% 0,15 \mathrm{ml}$ of humate potassium and 1,5 grams of bentonite in the experiment $\mathrm{Cu}, \mathrm{Mn}, \mathrm{Zn}, \mathrm{As}, \mathrm{Pb}, \mathrm{Cd}$ absorbent of heavy elements, the amount of dissolved in water in comparison with the control $57 \%, 46 \%, 49 \%, 7 \%, 54 \%, 68 \%$ and $55 \%, 45 \%, 37 \%, 11 \%, 49 \%$ reduction was determined.

\section{CONCLUSIONS}

Thus, studies have shown that the introduction into the soil of additives consisting of bentonite and humates in small quantities leads to the effective bonding of cations of heavy elements. In the soils studied, the main forms of $\mathrm{Cu}, \mathrm{Zn}, \mathrm{V}, \mathrm{Pb}$, and $\mathrm{Cr}$ were determined. The addition of detoxicants to the soil and their effect significantly reduces the harrowing content of heavy elements in the soils. The results of the studies for the study of humate and bentonite were found to have a positive effect on the use of soils contaminated with heavy elements.

\section{REFERENCES}

Reutse K., Kyrstya K. Fighting soil pollution. Moscow, Agropromizdat, (1986). 220 p

Hassan Z., Aarts M. G. M. Opportunities and feasibilities for biotechnological improvement of $\mathrm{Zn}, \mathrm{Cd}$ or $\mathrm{Ni}$ tolerance and accumulation in plants. Environmental and Experimental Botany, (2011). Vol. 72, No 1, pp. 53-63.

Ilyin V. B. Heavy metals in the "soil-plant" system. Novosibirsk, Nauka, (1991). 152 p.

Ilyin V. B. System of indicators for assessing soil contamination with heavy metals. Agrochemistry, (1995). No. 1, pp. 94-99.

Zubkova T.A., Karpachevsky L.O. Matrix organization of soils. Moscow, RUSAKI, (2001). 296 p.

Kloster N., Marcelo A. Interaction of humic acids with soil minerals: adsorption and surface aggregation induced by Ca2+. Environmental Chemistry, (2015). Vol. 12, No 6, pp. 731-738.

Hizal J., Apak R. Modelling of cadmium (II) adsorption on kaolinite-based clays in the absence and presence of humic acid. Applied Clay Science, (2006). Vol. 32, No 3-4, pp. 232-244 .

Zherebtsov S.I., Malyshenko N.V., Votolin K.S., Androkhanov V.A., Sokolov D.A. Humic preparations: Relation of structural group composition and biological activity. Bulletin of the Kuzbass state technical University, (2018), No. 5, pp. 52-60.

Arinzhanov A.E., Miroshnikova E.P., Rebezo M.B. Prospects for the use of humic substances. Electronic scientific and practical journal "Synergy", (2017), No. 1, pp. 105-109. 